\title{
FAKTOR-FAKTOR YANG MEMPENGARUHI SISA HASIL USAHA (SHU) PADA KOPERASI SYARIAH DI SURABAYA PADA PERIODE TAHUN 2014-20181
}

\author{
Anindya Nur Hidayati \\ Departemen Ekonomi Syariah-Fakultas Ekonomi dan Bisnis-Universitas Airlangga \\ Email: anindyaekis@gmail.com \\ Dian Filianti \\ Departemen Ekonomi Syariah-Fakultas Ekonomi dan Bisnis-Universitas Airlangga \\ Email: dian.filianti@gmail.com
}

\begin{abstract}
ABTRACT:
This study aims to analyze the influence of the number of members, own capital, and External capital on the Remaining Business Result (SHU) in Islamic cooperatives in Surabaya for the period 2014-2018. This study uses a quantitative approach. The subject used is the Sharia Cooperative in the Surabaya area with an annual period of 2014-2018. The method used in this study is a panel data regression analysis model that is processed using Stata software. Based on the results of the analysis it is shown that the variable number of members and own capital partially have a significant positive effect on SHU. Whereas, External capital has a negative significant effect on SHU. Nevertheless, simultaneously the number of members, own capital, and External capital have a significant effect on the Remaining Business Result (SHU).
\end{abstract}

Keywords: Remaining Business Result (SHU), Number of Members, Own Capital, External Capital.

\section{PENDAHULUAN}

Pelaku ekonomi di Indonesia dibagi menjadi tiga sektor yaitu pemerintah, swasta, dan koperasi. Pemerintah ikut berperan serta di dalam kegiatan perekonomian melalui BUMN dan kebanyakan didirikan dengan tujuan mencari laba. Sektor swasta ikut berperan serta dalam perekonomian dengan tujuan mencari laba, sedangkan koperasi didirikan dengan tujuan untuk mensejahterakan para anggotanya, sedang laba bukan merupakan tujuan Utama. Undang-Undang Dasar Pasal 33 ayat 1 menyebutkan Perekonomian disusun sebagai usaha bersama atas dasar asas kekeluargaan. Ayat ini mengandung esensi demokrasi ekonomi yaitu kemakmuran rakyat merupakan hal pokok yang diutamakan, produksi dalam organisasi dilakukan oleh semua anggota dan kepemilikannya oleh anggota sehingga dijadikan sebagai kontrol dalam pelaksanaan koperasi. Oleh karena itu dirasakan bentuk usaha yang cocok dengan asas kekeluargaan adalah koperasi.

Seiring berjalannya waktu, banyak bermunculan institusi keuangan berbasis Islam yang mengharamkan adanya bunga, karena tergolong ke dalam riba yang hukumnya haram dalam Islam. Kondisi ini meningkatkan kesadaran dan minat masyarakat akan lembaga keuangan Islam. Institusi keuangan berbasis syariah berkembang begitu pesat

\footnotetext{
${ }^{1}$ Jurnal ini merupakan bagian dari skripsi dari Anindya Nur Hidayati, NIM: 041211433010 , yang diuji pada 15 Juli 2019.
} 
Hidayati, et al/Jurnal Ekonomi Syariah Teori dan Terapan Vol. 6 No. 9 September 2019: 1862-1876; FAKTOR-FAKTOR YANG MEMPENGARUHI SISA HASIL USAHA (SHU) PADA KOPERASI SYARIAH DI SURABAYA PADA PERIODE TAHUN 2014-2018

dan cepat di Indonesia. Konsep ekonomi syariah mulai muncul pada tahun 1992 yaitu pada awal pendirian Bank Muammalat sebagai bank umum dengan prinsip bagi hasil dan bebas riba pertama di Indonesia. Munculnya lembaga keuangan Islam pertama ini memberikan pengaruh pada lembaga keuangan lain di Indonesia. Berbagai lembaga keuangan bank maupun non-bank yang berdasarkan prinsip syariah kemudian banyak bermunculan. Mayoritas penduduk Indonesia yang beragama Islam menjadikan pelvang besar berdirinya lembaga keuangan Islam dan terus berkembang.

Sebagai makhluk ciptaan Allah SWT, kita dianjurkan untuk menjadi orang yang bermanfaat dan saling membantu satu sama lain. Melalui koperasi, saling menolong dengan tujuan maju bersama dengan tidak membebani dengan syarat dan ketentuan-ketentuan yang rumit. Semangat saling menolong antar anggota koperasi itu sejalan dengan arahan Al-Qur'an. Allah SWT berfirman dalam Al-Qur'an Surat Al-Maidah (5) ayat 2:

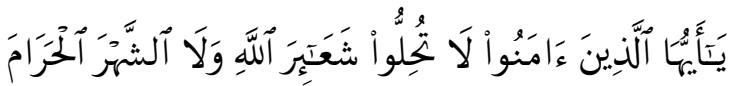

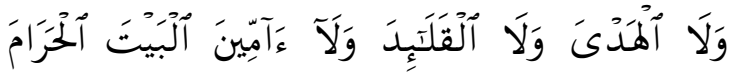

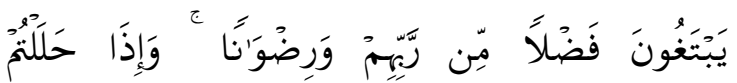

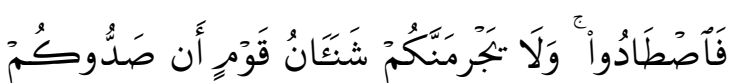

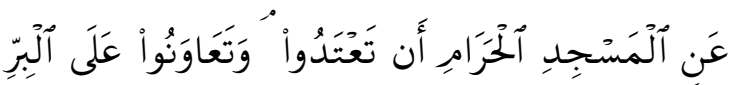

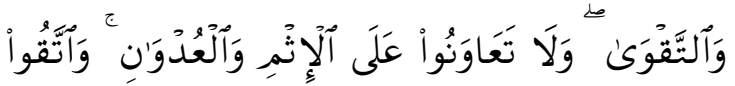

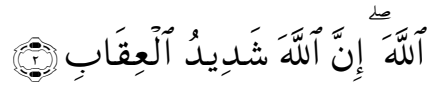

Yā ayyuhallażina āmanu lā tuhillu sya'ā irallāhi wa lasy-syahral-harāma wa lal-hadya wa lal-qalāiida wa lā āmminnalbaital-harāma yabtagụna faḍlam mir rabbihim wa rị̣wānā, wa iżā halaltum faștāâu, wa lā yajrimannakum syana ānu qaumin an șaddukum 'anil-masjidil-ḥarāmi an ta'tadu, wa ta'āwanu 'alal-birri wattaqwā wa lā ta'āwanu 'alal-ismi wal'udwāni wattaqullāh, innallāha syadídul'iqāb

Artinya: "Allah tidak melarang kamu untuk berbuat baik dan berlaku adil terhadap orang-orang yang tiada memerangimu karena agama dan tidak (pula) mengusir kamu dari negerimu. Sesungguhnya Allah menyukai orang-orang yang berlaku adil. Sesunguhnya Allah hanya melarang kamu menjadikan sebagai kawanmu orangorang yang memerangimu karena agama dan mengusir kamu dari negerimu dan membantu (orang lain) untuk mengusirmu. Dan barangsiapa mejadikan mereka sebagai kawan, maka mereka itulah orang-orang yang dzalim."

Koperasi memiliki peran penting dalam perekonomian Indonesia sehingga perlu optimalisasi kerja dan kinerja lembaga ini guna meningkatkan kesejahteraan masyarakat. Salah satu tolok-ukur yang digunakan koperasi, baik koperasi syariah maupun konvensional, untuk menilai tingkat kesejahteraan anggotanya adalah melalui jumlah sisa hasil usaha. Menurut Undang-Undang No.25 Tahun 1992 tentang Perkoperasian 
Hidayati, et al/Jurnal Ekonomi Syariah Teori dan Terapan Vol. 6 No. 9 September 2019: 1862-1876; FAKTOR-FAKTOR YANG MEMPENGARUHI SISA HASIL USAHA (SHU) PADA KOPERASI SYARIAH DI SURABAYA PADA PERIODE TAHUN 2014-2018

Pasal 45 Ayat 1, Sisa Hasil Usaha (SHU) adalah pendapatan koperasi yang didapat dalam satu tahun buku dikurangi biaya, penyusutan, dan kewajibankewajiban lain, termasuk pajak yang harus dibayarkan dalam tahun buku tersebut.

Perolehan sisa hasil usaha setiap tahun bagi koperasi menjadi sangat penting, karena sebagian dari SHU tersebut disisihkan sebagai cadangan yang akan memperkuat koperasi itu sendiri. Partisipasi yang aktif dari semua anggota koperasi terhadap semua kegiatan koperasi diharapkan dapat memperoleh sisa hasil usaha yang dari tahun ke tahun terus meningkat.

Koperasi memerlukan peran aktif pada anggotanya dalam segala kegiatan koperasi untuk dapat berkembang atas kekuatan sendiri. Peran aktif tersebut tercipta apabila terdapat perasaan memiliki sehingga secara efektif dapat mengambil keputusan koperasi. Para anggota juga berhak dan harus mampu menjalankan pengawasan atas jalannya usaha koperasi (K. Tjilik Suwito, dkk, 1991: 18).

Salah satu bentuk peranserta anggota di dalam koperasi yaitu dalam hal penanaman modal di koperasi. Besarkecilnya lapangan usaha koperasi juga memerlukan sejumlah modal yang harus dihimpun baik dari anggota maupun sumber lain. Modal diperoleh dari anggota, bukan anggota, pemerintah, badan usaha, koperasi lain dan bank. Modal dari anggota sendiri berasal dari simpanan pokok, simpanan wajib, simpanan sukarela dan modal yang terbentuk dari cadangan berbagai kegiatan yang dilakukan koperasi dalam usaha pencarian dana. Mengingat hal tersebut, maka jumlah anggota, modal sendiri dan modal luar sangat mungkin mempengaruhi besarnya sisa hasil usaha (SHU).

\section{LANDASAN TEORI}

\section{Koperasi Syariah}

Koperasi syariah adalah bentuk koperasi yang memiliki prinsip, tujuan, dan kegiatan usahanya berdasarkan syariah Islam, yaitu Al-Quran dan As-Sunnah. Secara umum, koperasi ini merupakan badan usaha yang menjalankan aktivitas usahanya berdasarkan pada prinsipprinsip syariah. Semua unit usaha, produk, dan operasional koperasi ini dilakukan sesuai dengan fatwa Dewan Syariah Nasional (DSN) Majelis Ulama Indonesia.

Koperasi syariah adalah lembaga keuangan masyarakat berbentuk koperasi, yang bekerja dengan landasan syariah Islam. Dengan perkataan lain koperasi syariah berbeda dengan koperasi konvensional dalam landasan sistemnya. Landasan sistem operasional koperasi syariah adalah Al-Qur'an Surat Al-Baqarah (2) ayat 275.
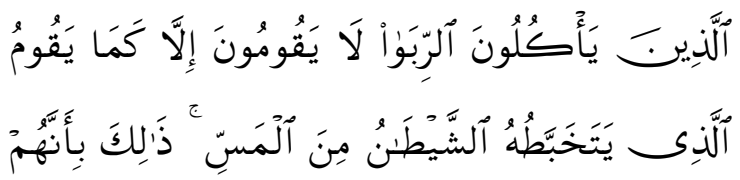

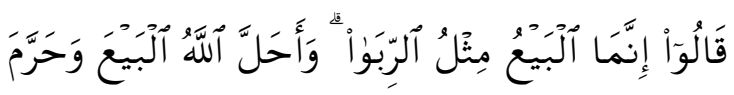

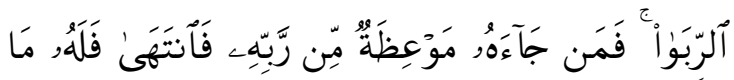


Hidayati, et al/Jurnal Ekonomi Syariah Teori dan Terapan Vol. 6 No. 9 September 2019: 1862-1876; FAKTOR-FAKTOR YANG MEMPENGARUHI SISA HASIL USAHA (SHU) PADA KOPERASI SYARIAH DI SURABAYA PADA PERIODE TAHUN 2014-2018

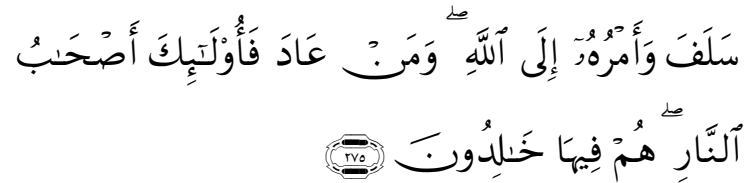

allażīna ya`kulụnar-ribā lā yaqụmuna illā kamā yaqưmullażī yatakhabbațuhusysyaitānu minal-mass, żālika bi annahum qālū innamal-bai'u mis̀lur-ribā, wa ahallallāhul-bai'a wa harramar-ribā, fa man jā’ahu mau'izatum mir rabbihī fantahā fa lahu mā salaf, wa amruhū ilallāh, wa man 'āda fa ulā ìka aṣ-hāabunnār, hum fihā khālidụn

Artinya: "Orang-orang yang memakan riba tidak dapat berdiri melainkan seperti berdirinya orang yang kemasukan setan karena gila. Yang demikian itu karena mereka berkata bahwa jual beli sama dengan riba. Padahal Allah telah menghalalkan jual-beli dan mengharamkan riba. Barangsiapa mendapat peringatan dari Tuhannya, lalu dia berhenti, maka apa yang telah diperolehnya dahulu menjadi miliknya dan urusannya (terserah) kepada Allah. Barangsiapa mengulangi, maka mereka itu penghuni neraka, mereka kekal di dalamnya."

Tujuan koperasi berbasis syariah ini adalah untuk meningkatkan taraf hidup anggotanya berupa kesejahteraan masyarakat yang ikut dalam perintisan perekonomian di Indonesia dengan prinsip dasar Islam. Koperasi syariah ini memiliki landasan syariah Islam yaitu AlQur'an dan As-Sunnah yang mewajibkan untuk tolong-menolong serta saling menguatkan. Selain itu, koperasi ini juga memiliki landasan pancasila serta undang-undang 1945 yang berasaskan kekeluargaan. Maka dari itu, fungsi koperasi syariah secara keseluruhan adalah membangun serta mengembangkan potensi serta kemampuan dari anggotanya, untuk meningkatkan kesejahteraan sosial ekonominya.

Koperasi syariah memiliki pola kerja yang sama dengan koperasi konvensional, termasuk keanggotaannya. Sesuai dengan Undang-Undang No. 25 Tahun 1992 tentang perkoperasian, bahwa anggota koperasi merupakan pemilik dan sekaligus pengguna jasa koperasi. Sehingga koperasi ini tidak dimiliki oleh perorangan, melainkan dimiliki oleh seluruh anggota koperasi dan pasar dari koperasi adalah anggotanya sendiri yang tidak melayani luar anggota.Jadi koperasi merupakan badan usaha yang dibentuk untuk memenuhi kebutuhan anggotanya, demi kemakmuran dan kesejahteraan bersama, tidak seperti badan usaha lainnya yang melayani masyarakat secara umum.

\section{Jumlah Anggota}

Berdasarkan Undang-Undang No. 25 Tahun 1992 tentang koperasi, salah satu syarat berdirinya koperasi di Indonesia adalah minimal 20 orang sebagai anggota. Dalam ketentuan Pasal 18 ayat (1) UU No. 25 Tahun 1992 tentang koperasi, disebutkan bahwa setiap warga negara Indonesia memiliki hak menjadi anggota koperasi, namun yang benar-benar 
Hidayati, et al/Jurnal Ekonomi Syariah Teori dan Terapan Vol. 6 No. 9 September 2019: 1862-1876; FAKTOR-FAKTOR YANG MEMPENGARUHI SISA HASIL USAHA (SHU) PADA KOPERASI SYARIAH DI SURABAYA PADA PERIODE TAHUN 2014-2018

diterima menjadi anggota koperasi adalah mereka yang mampu melakukan tindakan hukum atau tindakan koperasi karena koperasi merupakan sebuah bentuk badan hukum. Selain itu, anggota koperasi juga harus memenuhi persyaratan yang ada di anggaran dasar.

\section{Modal Koperasi}

Modal koperasi terdiri dari modal sendiri dan modal pinjaman. Modal sendiri dapat berasal dari simpanan pokok, simpanan wajib, dana cadangan danhibah. Sedangkan modal pinjaman dapat berasal dari anggota, koperasi lainnyaatau anggotanya, bank dan lembaga keuangan lainnya, penerbitan obligasidan surat hutang lainnya, serta sumber lainnya yang sah (UU No. 25 tahun 1992 Pasal 41 ayat 1 \& 2 tentang koperasi).

\section{Sisa Hasil Usaha (SHU)}

Istilah Sisa Hasil Usaha atau SHU dalam organisasi badan usaha koperasi dapat dipandang dari dua sisi. Dari sisi pertama, SHU ditentukan dari cara menghitungnya. Dari sisi kedua, sebagai badan usaha yang mempunyai karakteristik dan mempunyai nila-nilai tersendiri, maka sebutan Sisa Hasil Usaha merupakan makna yang berbeda dengan keuntungan atau laba dari badan usaha bukan koperasi. Sisi ini menunjukkan bahwa badan usaha koperasi bukan mengutamakan mencari laba tetapi mengutamakan memberikan pelayanan kepada anggotanya. Masalah kemudian menjalankan usahanya, koperasi menghasilkan laba yang di sebut "Sisa" Hasil Usaha, itu merupakan konsekuensi logis dari usaha uang dijalankan oleh koperasi tersebut adalah benar atau sehat; jadi tidak menuai kerugian.

Perhitungan akhir tahun yang menggambarkan penerimaan pendapatan koperasi dan alokasi penggunaannya untuk biaya-biaya koperasi berdasarkan Pasal 45 Ayat (1) UU RI No. 25 Tahun 1992 tentang koperasi, dapat dirumuskan sebagai berikut: $\mathrm{SHU}=$ Pendapatan - (Biaya + Penyusutan + Kewajiban lain + Pajak)

\section{METODE PENELITIAN}

\section{Pendekatan Penelitian}

Penelitian ini menggunakan pendekatan penelitian kuantitatif. Pendekatan penelitian kuantitatif adalah penelitian yang menitikberatkan pada pengujian hipotesis, data yang digunakan dalam penelitian harus terukur, dan menghasilkan kesimpulan yang dapat digeneralisasikan (Anshori dan Iswati, 2009:155). Penelitian ini akan menjelaskan hubungan antara sisa hasil usaha (SHU) dan faktor-faktor yang mempengaruhinya yaitu jumlah anggota, modal sendiri dan modal luar pada koperasi syariah di surabaya pada periode tahun 2014-2018. Penelitian ini bertujuan agar peneliti dapat memperoleh informasi dan tambahan pengetahuan secara detail mengenai faktor-faktor yang mempengaruhi jumlah SHU pada koperasi syariah di surabaya. 
Hidayati, et al/Jurnal Ekonomi Syariah Teori dan Terapan Vol. 6 No. 9 September 2019: 1862-1876; FAKTOR-FAKTOR YANG MEMPENGARUHI SISA HASIL USAHA (SHU) PADA KOPERASI SYARIAH DI SURABAYA PADA PERIODE TAHUN 2014-2018

\section{Definisi Operasional Variabel}

1. Jumlah Anggota

Anggota koperasi merupakan pemilik sekaligus juga sebagai pengguna jasa koperasi yang keanggotaannya dicatat dalam buku anggota. Di dalam penulisan ini, yang menjadi anggota adalah para anggota koperasi yang menjadi objek dalam penelitian ini, di mana setiap anggota memiliki hak dan kewajiban yang sama sebagimana diatur dalam anggaran dasar yang dihitung dengan satuan orang per koperasi.

2. Modal Sendiri

Dana yang diperoleh dari simpanan wajib anggota, simpanan pokok anggota, cadangan, dan hibah yang dihitung dengan satuan rupiah. Simpanan wajib dibayarkan sekali sewaktu anggota tersebut pertama kali bergabung dengan koperasi, simpanan pokok dibayarkan tiap bulan dengan nominal yang tidak harus sama antar anggota, cadangan merupakan cadangan modal sedangkan hibah merupakan pemberian sukarela dari anggota yang besarnya tidak sama.

3. Modal Luar

Dana yang diperoleh koperasi melalui pinjaman yangdihitung melalui satuan rupiah. Baik dari anggota, koperasi lainnya, bank dan lembaga keuangannya lainnya, penerbitan obligasi dan surat hutang lainnya serta sumber lain yang sah.
4. Sisa Hasil Usaha

Pendapatan koperasi yang diperoleh dalam satu tahun buku dikurangi dengan biaya penyusutan dan kewajiban lainnya termasuk pajak dalam buku yang bersangkutan.

\section{Jenis dan Sumber Data}

Jenis data yang digunakan dalam penelitian ini adalah data sekunder berupa data. Data sekunder diperoleh dari Dinas Koperasi dan Usaha Mikro Surabaya. Data yang diambil dari laporan keuangan koperasi syariah di Surabaya yaitu jumlah anggota, modal sendiri, modal luar, dan Sisa Hasil Usaha (SHU). Periode yang diambil dalam penelitian ini adalah 2014-2018.

Pada penelitian ini menggunakan analisis regresi berganda dengan data panel sebagai alat pengolahan data dengan menggunakan program Stata. Gujarati (2003:406) menjelaskan bahwa data panel adalah gabungan dari data time series dan cross section. Data time series merupakan data yang disusun berdasarkan urutan waktu, seperti data harian, bulanan, kuartal atau tahunan. Sedangkan data cross section merupakan data yang dikumpulkan pada waktu yang sama dari beberapa daerah, perusahaan, atau perorangan. Penggabungan kedua jenis data dapat dilihat bahwa variabel terikat sisa hasil usaha (SHU) terdiri dari beberapa unit koperasi syariah di Surabaya (cross section) dan menggunakan periode tahunan dari tahun 2014 sampai tahun 2018 (time 
Hidayati, et al/Jurnal Ekonomi Syariah Teori dan Terapan Vol. 6 No. 9 September 2019: 1862-1876; FAKTOR-FAKTOR YANG MEMPENGARUHI SISA HASIL USAHA (SHU) PADA KOPERASI SYARIAH DI SURABAYA PADA PERIODE TAHUN 2014-2018

series).

\section{Prosedur Pengumpulan Data}

Metode pengumpulan data dalam penelitian ini dengan melakukan studi pustaka mengkaji buku-buku, jurnal, makalah, dan sumber-sumber lain yang berkaitan dengan penelitian. Selain melakukan studi pustaka, peneliti mengumpulkan data laporan keuangan tahunan beberapa koperasi syariah di Surabaya dari Dinas Koperasi dan Usaha Mikro Surabaya.

\section{Populasi dan Sampel}

Populasi yang digunakan dalam penelitian ini adalah 20 koperasi syariah yang terdaftar di Dinas Koperasi dan Usaha Mikro Surabaya. Di mana populasi dalam penelitian ini diambil dari periode 2014 sampai dengan 2018 pada laporan keuangan koperasi yang dimiliki oleh Dinas Koperasi dan Usaha Mikro Surabaya.

Dalam penelitian ini pengambilan sampel dilakukan dengan menggunakan teknik purposive sampling, di mana sampel dipilih berdasarkan pertimbangan tertentu sesuai dengan tujuan penelitian. Menurut Sugiyono (2010:85) sampling purposive adalah teknik penentuan sampel berdasarkan tujuan dan pertimbangan tertentu.

Kriteria yang digunakan dalam penentuan sampel pada penelitian ini adalah:

1. Koperasi syariah yang terdaftar di Dinas Koperasi dan Usaha Mikro Surabaya pada periode penelitian yaitu pada tahun 2014-2018.
2. Koperasi syariah yang memiliki laporan keuangan selama periode 2014 sampai dengan periode 2018.

3. Koperasi syariah yang dijadikan sampel penelitian memiliki kelengkapan data yang berkaitan dengan data yang dibutuhkan sesuai dengan variabel yang digunakan.

Pada penelitian ini didapatkan sampel sebanyak 6 koperasi syariah di Surabaya. Data yang dianalisis dalam penelitian ini adalah data sekunder dengan periode tahunan antara tahun 2014 sampai dengan tahun 2018.

\section{Estimasi Regresi Data Panel}

1. Common Effect Model (CEM)

Pendekatan ini secara sederhana menggabungkan seluruh data time series dan cross section, kemudian mengestimasi model dengan menggunakan metode common effect model atau sering dikenal dengan pendekatan pooled least squares.

2. Fixed Effect Model (FEM)

Model ini merupakan estimasi data panel di mana pendekatan efek tetap dilakukan untuk memperbaiki asumsi teknik CEM yang jauh dari realita sebenarnya. Pendekatan efek tetap muncul karena perbedaan karakteristik setiap individu. Maka pendekatan efek tetap mengasumsikan adanya intersep yang dapat berbeda antar individu, namun intersep setiap perusahaan tidak bervariasi sepanjang waktu. Pendekatan efek tetap dapat 
Hidayati, et al/Jurnal Ekonomi Syariah Teori dan Terapan Vol. 6 No. 9 September 2019: 1862-1876; FAKTOR-FAKTOR YANG MEMPENGARUHI SISA HASIL USAHA (SHU) PADA KOPERASI SYARIAH DI SURABAYA PADA PERIODE TAHUN 2014-2018

diestimasi dengan teknik dummy variable.

3. Random Effect Model (REM)

Model ini merupakan estimasi data panel dimana pendekatan efek acak digunakan untuk memperbaiki efisiensi proses least squares dengan memperhitungkan error dari cross section dan time series. Random effect model adalah variasi dari estimasi generalized least squares, pendekatan ini mengasumsikan efek individu yang tidak terobservasi dan tidak berkorelasi dengan regressor atau dengan kata lain bersifat random.

\section{Pemilihan Model Regresi Data Panel}

1. Uji Chow

Uji Chow adalah pengujian untuk menentukan model Common Effect Model atau Fixed Effect Model yang paling tepat digunakan dalam mengestimasi data panel. Dalam melakukan Uji Chow, data diregresikan dengan menggunakan Common Effect Model dan Fixed Effect Model terlebih dahulu, kemudian dibuat hipotesis untuk diuji. Hipotesis tersebut adalah sebagai berikut.

2. Uji Hausman

Uji Hausman adalah pengujian statistik untuk memilih apakah Fixed Effect Model atau Random Effect Model yang paling tepat digunakan. Dalam melakukan uji Hausman, data diregresikan dengan menggunakan Random Effect Model terlebih dahulu kemudian dibuat hipotesis untuk diuji.
Hipotesis tersebut adalah sebagai berikut.

3. Uji Lagrange Multiplier

Lagrange Multiplier (LM) adalah uji untuk mengetahui apakah Random Effect Model (REM) atau Pooled Least Square (PLS) metode yang paling tepat digunakan (Widarjono, 2009).

\section{Uji Asumsi Klasik}

1. Uji Normalitas

Uji normalitas digunakan untuk menguji apakah dalam sebuah model regresi, variabel pengganggu atau residual memiliki distribusi yang normal. Model regresi yang baik adalah data yang memiliki distribusi normal atau mendekati normal.

2. Uji Multikolinearitas

Menurut Ghozali (2011:105-106) uji multikolinearitas bertujuan untuk menguji apakah model regresi ditemukan adanya korelasi antar variabel bebas (independen).

3. Uji Heterokedastisitas

Menurut Ghozali (2011:139), uji heterokedastisitas bertujuan untuk menguji apakah model regresi terjadi ketidaksamaan varians dalam satu pengamatan terhadap pengamatan lainnya. Model regresi yang baik adalah homokedastisitas atau varians dari satu pengamatan ke pengamatan lain tetap. Uji heterokedastisitas dapat menggunakan grafik plot dengan melihat ada tidaknya pola tertentu dalam grafik. 
Hidayati, et al/Jurnal Ekonomi Syariah Teori dan Terapan Vol. 6 No. 9 September 2019: 1862-1876;

FAKTOR-FAKTOR YANG MEMPENGARUHI SISA HASIL USAHA (SHU) PADA KOPERASI SYARIAH DI SURABAYA

PADA PERIODE TAHUN 2014-2018

\section{Uji Hipotesis}

1. Uji F

Uji statistik F pada dasarnya menunjukkan apakah semua variabel independen atau variabel bebas yang dimasukkan dalam model mempunyai pengaruh secara bersama-sama terhadap variabel dependennya (Ghazali, $2011: 98$ ).

2. Uji $†$

Uji statistik $†$ pada dasarnya menunjukkan seberapa jauh pengaruh satu variabel penjelas atau independen secara individual dalam menerangkan variasi variabel dependen (Ghozali, 2011 1:98).

3. Uji Koefisien Determinasi

Menurut Ghozali (2011:97), uji koefisien determinasi $\left(R^{2}\right)$ bertujuan untuk mengukur seberapa jauh kemampuan model dalam menerangkan variasi variabel dependen.

\section{HASIL DAN PEMBAHASAN}

\section{Deskripsi Hasil Penelitian}

Penelitian ini bertujuan untuk menganalisis pengaruh jumlah anggota, modal sendiri dan modal luar terhadap sisa hasil usaha (SHU) pada koperasi syariah di Surabaya periode tahun 20142018. Metode yang digunakan dalam penelitian ini adalah model analisis regresi data panel yang dihitung menggunakan perangkat lunak Stata. Tingkat signifikansi yang digunakan adalah sebesar 0,05 atau $5 \%$. Tabel berikut ini menunjukkan statistik deskriptif variabel jumlah anggota, modal sendiri, modal luar dan SHU.
Tabel 1.

Deskripsi Variabel Penelitian Tahun 20142018

Deskripsi Variabel Penelitian Tahun 2014-2018

\begin{tabular}{|l|c|c|c|c|c|}
\hline \multicolumn{1}{|c|}{ Variabel } & N & Mean & Std. Dev. & Min & Max \\
\hline Jumlah Anggota & 30 & 136,6 & 102,3138 & 20 & 494 \\
\hline Modal Sendiri & 30 & $3.65 \mathrm{e}+08$ & $2.55 \mathrm{e}+08$ & $2.86 \mathrm{e}+07$ & $1.02 \mathrm{e}+09$ \\
\hline Modal Luar & 30 & $9.30 \mathrm{e}+08$ & $1.34 \mathrm{e}+09$ & 1020000 & $4.09 \mathrm{e}+09$ \\
\hline SHU & 30 & $9.08 \mathrm{e}+07$ & $8.68 \mathrm{e}+07$ & 1374000 & $3.64 \mathrm{e}+08$ \\
\hline
\end{tabular}

Berdasarkan tabel 1, menunjukkan bahwa jumlah anggota minimum dimiliki oleh koperasi 3 pada tahun 2014 dan jumlah anggota maximum dimiliki oleh koperasi koperasi 1 pada tahun 2018. Modal sendiri minimum dimiliki oleh koperasi 3 pada tahun 2014 dan modal sendiri maximum dimiliki oleh koperasi koperasi 2 pada tahun 2018. Modal luar minimum dimiliki oleh koperasi 4 pada tahun 2014 dan modal sendiri maximum dimiliki oleh koperasi koperasi 6 pada tahun 2016. SHU minimum dimiliki oleh koperasi 3 pada tahun 2015 dan SHU maximum dimiliki oleh koperasi koperasi 2 pada tahun 2018.

\section{Uji Chow}

\section{Tabel 2.}

Uji Chow

\begin{tabular}{|c|c|c|}
\hline Effect Test & Prob. & Ket. \\
\hline Cross-section $\mathrm{F}$ & 0,074 & $\mathrm{H}_{0}$ Diterima \\
\hline
\end{tabular}

Berdasarkan tabel 2, hasil uji Chow menunjukkan bahwa probabilitas Crosssection $F$ yaitu sebesar 0,074. Dengan menggunakan taraf signifikansi 5\% maka nilai Cross-section $F>0,05$, hal tersebut menunjukkan bahwa $\mathrm{H}_{0}$ diterima dan $\mathrm{H}_{1}$ ditolak. Sehingga model terbaik untuk penelitian ini adalah menggunakan Common Effect Model (CEM). 


\section{Uji Hausman}

Tabel 3.

Uji Hausman

\begin{tabular}{|c|c|c|}
\hline Effect Test & Prob. & Ket. \\
\hline Cross-section Chi-square & 0,139 & $\mathrm{H}_{0}$ Diterima \\
\hline
\end{tabular}

Berdasarkan tabel 3, hasil uji Hausman menunjukkan bahwa probabilitas Cross-section Chi-square yaitu sebesar 0,139. Dengan menggunakan taraf signifikansi $5 \%$ maka nilai Crosssection $>0,05$, hal tersebut menunjukkan bahwa $\mathrm{H}_{0}$ diterima dan $\mathrm{H}_{1}$ ditolak. Sehingga model terbaik untuk penelitian ini adalah menggunakan Random Effect Model (REM).

Uji Lagrange Multiplier

Tabel 4.

Uji Lagrange Multiplier

\begin{tabular}{|c|c|c|}
\hline Effect Test & Prob. & Ket. \\
\hline Cross-section Chi-Square & 0,1963 & $\mathrm{H}_{0}$ Diterima \\
\hline
\end{tabular}

Berdasarkan tabel 4, uji lagrange multiplier menunjukkan bahwa probabilitas Cross-section Chi-square yaitu sebesar 0,1963. Dengan menggunakan taraf signifikansi $5 \%$ maka nilai Crosssection > 0,05, hal tersebut menunjukkan bahwa $\mathrm{H}_{0}$ diterima dan $\mathrm{H}_{1}$ ditolak. Sehingga model terbaik untuk penelitian ini adalah menggunakan Common Effect Model (CEM).

\section{Uji Normalitas}

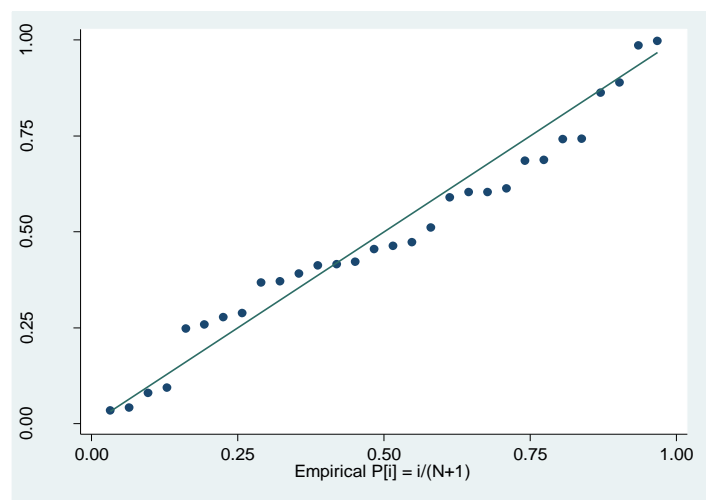

Gambar 1.

Uji Normalitas

Berdasarkan gambar 1, menggambarkan bahwa data menunjukkan pola distribusi normal. Hal tersebut dapat dilihat data menyebar disekitar garis diagonal dan mengikuti arah garis diagonal atau grafik histogramnya, maka model regresi memenuhi asumsi normalitas.

\section{Uji Heterokedastisitas}

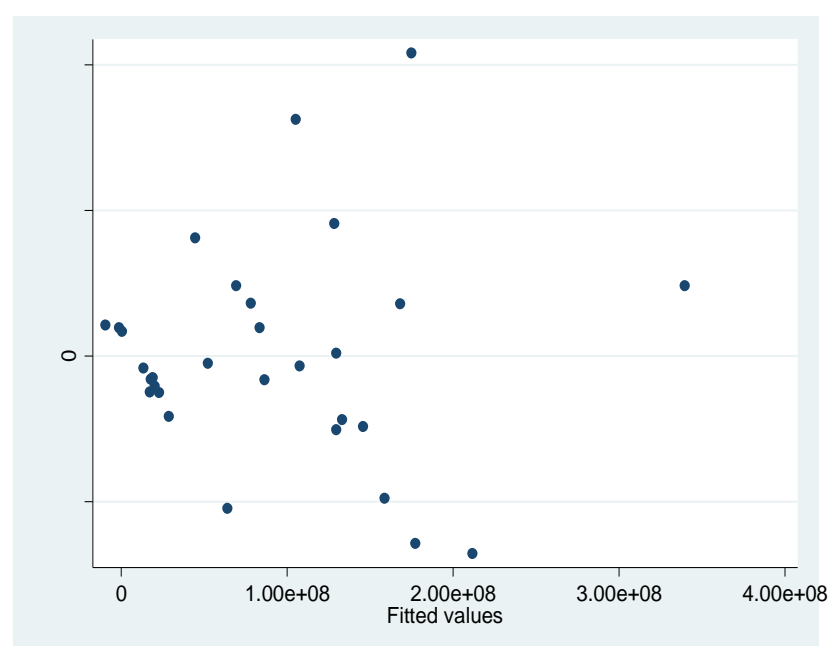

\section{Gambar 2.}

Uji Heterokedastisitas

Berdasarkan gambar 2, diketahui bahwa titik menyebar dan tidak membentuk pola data tertentu. Sehingga dapat disimpulkan bahwa tidak terjadi heterokedastisitas yaitu terjadi ketidaksamaan varian dari residual varian 
Hidayati, et al/Jurnal Ekonomi Syariah Teori dan Terapan Vol. 6 No. 9 September 2019: 1862-1876; FAKTOR-FAKTOR YANG MEMPENGARUHI SISA HASIL USAHA (SHU) PADA KOPERASI SYARIAH DI SURABAYA PADA PERIODE TAHUN 2014-2018

satu pengamatan dengan pengamatan lain. Model regresi terbebas dari gejala heterokedastisitas, lolos uji asumsi klasik uji heterokedastisitas dan layak digunakan sebagai model regresi.

Uji Multikolinearitas

Tabel 5.

Uji Multikolinearitas

\begin{tabular}{|l|c|}
\hline \multicolumn{1}{|c|}{ Variabel } & VIF \\
\hline Jumlah & 2,74 \\
Anggota & \\
\hline $\begin{array}{l}\text { Modal } \\
\text { Sendiri }\end{array}$ & 2,50 \\
\hline Modal Luar & 1,18 \\
\hline
\end{tabular}

Berdasarkan tabel 5, diketahui bahwa nilai VIF semua variabel < 10, maka tidak ada multikolinearitas terhadap data yang divji dan tidak ada korelasi yang terjadi antara variabel independen yang digunakan dalam penelitian ini. Model regresi bebas dari multikolinearitas, lolos uji asumsi klasik uji multikolinearitas dan layak digunakan sebagai model regresi.

Uji Simultan (F-test)

Tabel 6.

Hasil Uji Simultan (F-Test)

\begin{tabular}{|c|c|}
\hline F-statistic & 38,71 \\
\hline Prob (F-statistic) & 0,0000 \\
\hline
\end{tabular}

Berdasarkan tabel 6, model terbaik adalah Common Effect Model (CEM). Nilai probabilitas F-statistic sebesar 0,0000 yang berarti bahwa nilai probabilitas kurang dari tingkat signifikan $0,05(5 \%)$, maka $\mathrm{H}_{0}$ ditolak dan $\mathrm{H}_{1}$ diterima. Dapat disimpulkan bahwa variabel jumlah anggota, modal sendiri dan modal luar secara simultan berpengaruh signifikan terhadap sisa hasil usaha (SHU).
Uji Parsial (t-test)

Tabel 7.

Hasil Uji Parsial (t-test)

\begin{tabular}{|c|c|c|c|c|}
\hline Variabel & Coef & Prob. & a. & Ket. \\
\hline Jumlah Anggota & 485007,9 & 0,000 & \multirow{3}{*}{0,05} & $\mathrm{H}_{1}$ diterima \\
\hline Modal Sendiri & 0,1217261 & 0,012 & & $\mathrm{H}_{1}$ diterima \\
\hline Modal Luar & 0,0071428 & 0,239 & & $\mathrm{H}_{0}$ diterima \\
\hline
\end{tabular}

Berdasarkan tabel 7, maka dapat

disimpulkan sebagai berikut.

1. Variabel jumlah anggota memiliki nilai probabilitas sebesar 0,000 yang berarti bahwa nilai probabilitas kurang dari tingkat signifikan 0,05 (5\%), maka $\mathrm{H}_{0}$ ditolak dan $\mathrm{H}_{1}$ diterima. Hal ini menunjukkan bahwa jumlah anggota berpengaruh positif signifikan terhadap sisa hasil usaha (SHU).

2. Variabel modal sendiri memiliki nilai probabilitas sebesar 0,012 yang berarti bahwa nilai probabilitas kurang dari tingkat signifikan 0,05 (5\%), maka $\mathrm{Ho}_{0}$ ditolak dan $\mathrm{H}_{1}$ diterima. $\mathrm{Hal}$ ini menunjukkan bahwa modal sendiri berpengaruh positif signifikan terhadap sisa hasil usaha (SHU).

3. Variabel modal luar memiliki nilai probabilitas sebesar 0,239 yang berarti bahwa nilai probabilitas lebih dari tingkat signifikan 0,05 (5\%), maka $\mathrm{H}_{0}$ diterima dan $\mathrm{H}_{1}$ ditolak. Hal ini menunjukkan bahwa modal luar berpengaruh negatif tidak signifikan terhadap sisa hasil usaha (SHU).

\section{Koefisien Determinasi $\left(\mathbf{R}^{2}\right)$}

Tabel 8.

Hasil Koefisien Determinasi $\left(\mathbf{R}^{2}\right)$

\begin{tabular}{|l|l|}
\hline R-Squared & 0,8171 \\
\hline Adjusted R-Squared & 0,7960 \\
\hline
\end{tabular}


Hidayati, et al/Jurnal Ekonomi Syariah Teori dan Terapan Vol. 6 No. 9 September 2019: 1862-1876; FAKTOR-FAKTOR YANG MEMPENGARUHI SISA HASIL USAHA (SHU) PADA KOPERASI SYARIAH DI SURABAYA PADA PERIODE TAHUN 2014-2018

Berdasarkan tabel 8, koefisien determinasi pada penelitian ini sebesar 0,8171 atau $81,71 \%$. Sehingga dapat disimpulkan bahwa variabel jumlah anggota, modal sendiri dan modal luar dapat menjelaskan $81,71 \%$ dari variabel sisa hasil usaha (SHU) pada koperasi syariah di Surabaya periode tahun 20142018 dan sisanya 18,29\% dipengaruhi oleh variabel lain yang tidak digunakan dalam penelitian ini.

\section{Pengaruh Jumlah Anggota Terhadap Sisa Hasil Usaha (SHU)}

Peran aktif anggota merupakan kunci keberhasilan suatu organisasi (badan hukum lainnya) dalam menjalankan usaha koperasi. Yang berarti dapat dikatakan juga peran aktif anggota dalam koperasi dapat dirumuskan sebagai keterlibatan para anggota secara aktif dan menyeluruh dalam pengambilan keputusan, penetapan kebijakan, arah dan langkah usaha, pengawasan terhadap jalannya usaha koperasi, penyertaan modal usaha, dalam pemanfaatan usaha, serta dalam menikmati sisa hasil usaha.

Berdasarkan hasil uji t, dapat diketahui bahwa variabel jumlah anggota berpengaruh positif signifikan terhadap sisa hasil usaha (SHU). Hal tersebut menjelaskan bahwa apabila jumlah anggota mengalami kenaikan maka sisa hasil usaha (SHU) koperasi syariah juga mengalami kenaikan, begitu pula sebaliknya.

Hasil penelitian ini sejalan dengan penelitian Sigit (2014) yang berjudul "Pengaruh Modal Sendiri, Jumlah Anggota, dan Aset terhadap Sisa Hasil Usaha pada Koperasi Kediri". Pada penelitian tersebut menyatakan bahwa jumlah anggota mempunyai pengaruh yang signifikan terhadap sisa hasil usaha. Hal tersebut berarti bahwa apabila jumlah anggota koperasi yang diteliti bertambah, maka akan mengakibatkan jumlah sisa hasil usaha pada koperasi akan meningkat karena hasil signifikansinya positif.

\section{Pengaruh Modal Sendiri Terhadap Sisa Hasil Usaha (SHU)}

Modal sendiri harus dikelolah pengurus semaksimal dan seoptimal mungkin agar anggota mendapat bagian SHU yang besar. Sehingga dengan dana yang besar perputaran dananya pun juga akan semakin luas yaitu digunakan untuk modal usaha lainnya dan perputaran roda ekonomi koperasi.

Berdasarkan hasil uji t, dapat diketahui bahwa variabel modal sendiri berpengaruh positif signifikan terhadap sisa hasil usaha (SHU). Hal tersebut menjelaskan bahwa apabila modal sendiri mengalami kenaikan maka sisa hasil usaha (SHU) koperasi syariah juga mengalami kenaikan, begitu pula sebaliknya.

Hasil penelitian ini sejalan dengan penelitian sigit (2014) yang berjudul "Pengaruh Modal Sendiri, Jumlah Anggota, dan Aset terhadap Sisa Hasil Usaha pada Koperasi Kediri". Pada 
Hidayati, et al/Jurnal Ekonomi Syariah Teori dan Terapan Vol. 6 No. 9 September 2019: 1862-1876; FAKTOR-FAKTOR YANG MEMPENGARUHI SISA HASIL USAHA (SHU) PADA KOPERASI SYARIAH DI SURABAYA PADA PERIODE TAHUN 2014-2018

penelitian tersebut menyatakan bahwa modal sendiri mempunyai pengaruh yang signifikan terhadap sisa hasil usaha (SHU). Penelitian tersebut membuktikan bahwa dengan bertambahnya modal sendiri, koperasi akan mengalami kenaikan sisa hasil usaha (SHU).

\section{Pengaruh Modal Luar Terhadap Sisa Hasil} Usaha (SHU)

Modal yang terbaik adalah modal sendiri tanpa adanya pinjaman modal dari yang lainnya. Namun karena modal sendiri kurang mencukupi untuk pengembangan usaha yang dilakukan koperasi, maka diperlukanlah bantuan dari luar sebagai pinjaman modal. Pinjaman ini diperoleh dari bantuan atau pinjaman pemerintah dan lain-lain.

Berdasarkan hasil uji t, dapat diketahui bahwa variabel modal luar berpengaruh negatif tidak signifikan terhadap sisa hasil usaha (SHU). Hasil penelitian ini sejalan dengan penelitian Novi (2009). Modal luar dalam penelitian tersebut tidak berpengaruh signifikan, hal itu menunjukkan bahwa modal luar belum mampu menambah modal kerja secara signifikan. Modal luar yang tersedia tidak dapat dimanfaatkan secara optimal oleh anggota maupun pengurus koperasi sehingga tidak mempengaruhi SHU.

Pengaruh Jumlah Anggota, Modal Sendiri, dan Modal Luar Terhadap Sisa Hasil Usaha (SHU)

Berdasarkan hasil uji F, dapat disimpulkan bahwa variabel jumlah anggota, modal sendiri dan modal luar secara simultan berpengaruh signifikan terhadap sisa hasil usaha (SHU) dengan nilai probabilitas F-statistic sebesar 0,0000. Nilai probabilitas kurang dari tingkat signifikan 0,05 (5\%), sehingga dalam penelitian ini variabel independen berpengaruh secara simultan terhadap variabel dependen.

$$
\text { Berdasarkan uji koefisien }
$$

determinasi menunjukkan nilai koefisien determinasi pada penelitian ini sebesar 0,8171 atau $81,71 \%$. Sehingga dapat disimpulkan bahwa variabel jumlah anggota, modal sendiri dan modal luar dapat menjelaskan $81,71 \%$ dari variabel sisa hasil usaha (SHU) pada koperasi syariah di Surabaya periode tahun 20142018 dan sisanya 18,29\% dipengaruhi oleh variabel lain yang tidak digunakan dalam penelitian ini.

\section{v. SIMPULAN}

Secara parsial jumlah anggota dan modal sendiri bepengaruh positif signifikan terhadap SHU. Sedangkan modal luar berpengaruh negatif tidak signifikan terhadap sisa hasil usaha (SHU). Secara simultan jumlah anggota, modal sendiri dan modal luar berpengaruh signifikan terhadap sisa hasil usaha (SHU).

\section{Saran}

1. Bagi Koperasi Syariah

Koperasi syariah dalam meningkatkan sisa hasil usaha (SHU) dapat dilakukan dengan menambah variabel jumlah anggota dan modal sendiri, sehingga dengan menambah jumlah anggota dan modal sendiri akan meningkatkan 
Hidayati, et al/Jurnal Ekonomi Syariah Teori dan Terapan Vol. 6 No. 9 September 2019: 1862-1876;

FAKTOR-FAKTOR YANG MEMPENGARUHI SISA HASIL USAHA (SHU) PADA KOPERASI SYARIAH DI SURABAYA

PADA PERIODE TAHUN 2014-2018

SHU yang juga akan meningkatkan keuntungan bagi koperasi.

2. Bagi peneliti selanjutnya

Disarankan pada penelitian selanjutnya agar menambah variabel independen lainnya, misal menggunakan variabel pembiayaan, aset, jumlah pengurus dan subjek penelitian lainnya atau menggunakan variabel dependen lain.

\section{DAFTAR PUSTAKA}

Anggraini, Novi Hasti. 2009. "Analisis FaktorFaktor Yang Mempengaruhi Sisa Hasil Usaha Koperasi Pegawai Negeri Di Kota Surakarta Tahun 2007". Universitas Sebelas Maret (Online). eprints.uns.ac.id, diakses pada 27 Juni 2017.

Anshori, Muslich dan Sri Iswati. 2009. Buku Ajar Metode Penelitian Kuantitatif. Surabaya: Pusat Penerbitan dan Percetakan Unair (AUP).

Arifin, Zainul. 2009. Dasar-Dasar Manajemen Bank Syariah. Jakarta: Raja Grafindo Persada.

Azim, Amin. 1987. Perkoperasian Indonesia. Yogyakarta: BPFE

Baswir, Revrisond. 2000. Koperasi Indonesia. Yogyakarta: BPFEYOGYAKARTA.

Buchori, Nur Syamsudin. 2009. Koperasi Syariah. Sidoarjo: Masmedia Buana Pustaka.

Departemen Koperasi. Undang-Undang Republik Indonesia No. 25 Tahun 1992. Tentang Perkoperasian.

Dewan Syariah Nasional. 2000. Fatwa No. 15/DSN-MUI/IX/2000. (Online). www.dsnmui.or.id, diakses pada 29 Januari 2019.

Firdaus, Muhammad dan Agus Endi Susanto. 2004. Perkoperasian Sejarah,Teori dan Praktek. Bogor: Ghalia Indonesia.

Ghozali, Imam. 2006. Analisis Multivariate dengan Program SPSS. Semarang: Badan Penerbit Universitas Diponegoro.

Hendrojogi. 1998. Koperasi Asas-Asas Teori dan Praktek. Jakarta: PT Raja Grafindo Persada.

Nazir, Mohammad. 1983. Metode Penelitian. Jakarta: Ghalia Indonesia.

Sagimun. 1983. Koperasi Indonesia. Jakarta: Departemen Pendidikan dan Kebudayaan.

Sedarmayanti, Syarifudin Hidayat. 2002. Metodologi Penelitian. Bandung: Mandar Maju.

Sholihin, Ahmad Ifham. 2008. Buku Pintar Ekonomi Syariah. Jakarta: PT Gramedia Pustaka Utama.

Sitio, Arifin dan Halomoan Tamba. 2001. Koperasi: Teori dan Praktek. Jakarta: Erlangga.

Suwito, K. Tjilik dkk. 1991. Peran Serta Anggota dan Pengembangan Koperasi Suatu Pengkajian Fungsional di Kotamadia Dati ॥ Surakarta. Laporan Penelitian Mandiri. Universitas Sebelas Maret Surakarta.

Widiyanti, Ninik dan YW Sunindhia, SH. 1989. Koperasi dan Perekonomian 
Hidayati, et al/Jurnal Ekonomi Syariah Teori dan Terapan Vol. 6 No. 9 September 2019: 1862-1876; FAKTOR-FAKTOR YANG MEMPENGARUHI SISA HASIL USAHA (SHU) PADA KOPERASI SYARIAH DI SURABAYA PADA PERIODE TAHUN 2014-2018

Indonesia. Jakarta: PT Bina Aksara.

Winarko, Sigit Puji. 2014. "Pengaruh Modal Sendiri, Jumlah Anggota, dan Aset Terhadap Sisa Hasil Usaha Pada Koperasi di Kota Kediri". Nusantara Of Research (Online). efektor.unpkediri.ac.id, diakses pada 1 Februari 2019. 